\title{
DEVELOPING A MODEL FOR PRE- ACTION DISPUTE RESOLUTION FOR STRATA DISPUTE MANAGEMENT IN MALAYSIA
}

\section{Nor Asiah Mohamad}

Assoc Professor, Dept of Civil Law, AIKOL, International Islamic University Malaysia, Kuala Lumpur, Malaysia. Email: nasiahm@iium.edu.my

\begin{abstract}
The Malaysian government has finally announced for the implementation of Strata Management Act 2013 with the aims to cater disputes in the management of strata titled properties. Among the most important aspect of the Act is to introduce Strata Management Tribunal as a platform to resolve disputes among the strata owners and all stakeholders in relation to strata management and maintenance. This research addresses the period prior to the adjudication process by the Tribunal and proposes a model for early dispute resolution before the hearing. The author argues that early dispute resolution or early conflict engagement is necessary despite the establishment of Strata Management Tribunal to address non-technical issues, which involve restoration of social relationship. The author highlights the practice of other jurisdiction, for example, Victoria, Australia as well Hong Kong. The findings of the research show that Alternative Dispute Resolution (ADR) methods such as mediation or conciliation are suitable to be adopted within and outside Tribunal process.
\end{abstract}

Keywords: stratified properties, Strata Management Tribunal, Strata Management Act, mediation, conciliation and Alternative Dispute Resolution (ADR)

\section{Introduction}

There are various issues and problems revolving around the management of strata titled properties in Malaysia. The problems exist as early as the issuance of the strata title till the management of the properties after the titles are issued. The problems also vary and can be so technical which require an expert opinion. While problems on late issuance of strata title has been gradually resolved with the introduction and the amendments to the Strata titles Act 1985 , the problems on management of strata or stratified properties seem to be continuously haunting various stakeholders in strata management.

Many would generally hold to the view that the best way to resolve problems is to face the problems. This view sometimes works better for strata properties. The problems can be resolved by people involved in the disputes to talk about their problems and fulfilling their expected responsibilities. Nevertheless, the success depends on the types and seriousness of the problems. In some cases, more technical efforts may be required to address the issues. In addressing these issues, the Strata Management Act 2013 have engaged some approaches to improve the way strata disputes are resolved in particular through the establishment of the Tribunal. Under the Strata Titles Act 1985 when issues cannot be resolved informally, the laws offer a number of mechanisms to resolve disputes, including reference to the High Court for serious matters and reference to the Strata Titles Board. These approaches may not be suitable to all cases involving strata while the Strata Titles Board has in fact failed to exist. Having stated the earlier scenario, it is acknowledged that strata living are unique. Its uniqueness depends on teamwork, cooperation, sense of belonging and harmonization among the owners and residents. Furthermore, the value of their properties depends on their cooperation and common effort to maintain their properties. The tagline "United we stand, divided we fall" is close to their hearts or their lives will be stressful and miserable. 
The expectation to self- regulate the properties may sometimes become a burden to some. For smooth sailing of the maintenance and management, the government took several legal initiatives to ensure all parties take part and take full responsibility of their own properties as well as the common properties. At present, the owners of strata properties have to act as the Chairman till the manager of their properties. Even though the law has been designed to prepare a step by step guideline on how to manage especially the common properties financially and administratively, dissatisfactions do arise from times to times. Alleged mismanagement of fund, lack of understanding of the law, cronyism, political inclination, are among the common complaint on the strata managers among the Joint Management Body or the Management Corporation committees (Nor Asiah, 2015). Moreover, there are always disagreement and lack of civic awareness among the residents. Complaints such as noises, parking, cleanliness, inter-floor leakage, pet, misuse of the common area is common (Nor Asiah M., 2015).

Having mentioned the various types and diverse nature of the problems, it is argued that a straight forward selfmanaged problem resolution or the strict, costly and long court process may be not the best mechanism to resolve strata management problems. Studies from various jurisdictions which have advanced in strata properties' management show that alternative dispute resolution (ADR) modes are successfully engaged and are well received by the people. ADR is encouraged for the fact that it allows the parties in dispute to decide what the best way to resolve their problem is. It also allows them to participate in the process and making their own decisions. This approach is suitable and appropriate for self-managed strata as practiced in Malaysia.

Historically, strata titled properties were originally developed as a way of allowing individuals to own a unit of a flat or an apartment within multi-level buildings. Under the first legislation on strata i.e. the Strata Titles Act 1985 (Act 318), there was no express provision governing matters concerning disputes. This may be associated to less number of strata and thus fewer problems would occur. The previous reports recorded a number of high complaints on strata without a title and where the dispute occurred between owners and the Management Corporation or the Managing agent concerning the maintenance of properties. Most of the problems were probably resolved amicably or by referring to the contract entered into by the parties in the sale and purchase agreement. In 1990, the Strata Titles Act 1985 (Act No 753), although there was no provision in the Act for alternative dispute resolution, the management could resolve problems of non-payment of maintenance fee by attachment of property of owners in arrears (section 53 and Form 7). In addition, the State Authority is given the power to fine those who fail to comply with the provisions of the Act, an amount determined by the Act or the Regulations but if there is no provision as such, he can be fined of not more than RM2000.00. Section 40(1)(2) of the STA gives the right to the owner and the MC to seek damages for losses arising from breach of contract by the parcel owner through court referral. Obviously, no other means of resolving disputes appear in the STA 1985 but litigation. Another amendment to STA 1985 was made in 1996 via Act 951 with a specific aim to improve the problem of long delay in getting strata title. It also allows for strata title to be issued for single storey building if they formed part of the mixed project which comprised of multi-storey and single-storey projects. Again, the amendment did not formally address for any structured dispute resolution but parties may seek help from the related Ministries in case of any problem. In 2001 the STA 1985 was amended to include provisions for the establishment of Strata Titles Board (STB) (section 67A$\mathrm{X}$ ) which aims to resolve disputes faced by the Management Corporation (MC). By having this Board, all disputes between parcel owners and the MC can be resolved without going to the court. The Strata Titles Board has never been established in all states in Malaysia (Nor Asiah M., 2013).

\section{Nature and types of disputes}

The disputes are determined on various bases. The nature and types of complaints on strata properties received by various agencies under the related ministries are assumed to be a basis for disputes. In addition, research findings on problems and issues on strata are also taken as possible cause for dispute. It was reported that the Ministry received about 15,000 complaints on various matters pertaining to strata properties after the introduction of the Building and Common Property (Maintenance and Management) Act 2007. It was also reported in the Malaysian Bar website that failure to pay maintenance fee or known as and other contributions to the developer, with the parcel owners having no say in the amount of the monthly charges and the standard of service provided are among the major complaints on strata properties. Nevertheless, some of these problems were resolved when the Building and Common Property (Maintenance and Management) Act 2007 was introduced, as this Act establishes a Joint Management Body (JMB). 
The establishment of the STB has a positive initiative as it is a specialised tribunal to deal with disputes between parcel proprietors and Management Corporation and among the parcel proprietors themselves. Since the procedures are simple, it provides speedy settlement at a low cost. It is supposed to be effective as any person who contravenes an order made by the Board to do or refrain from doing a specified act shall be liable on conviction to a fine not exceeding RM10,000 or imprisonment for a term not exceeding two years or to both. It is also provided that the decision of the Board is final and no appeal shall lie to the High Court except on a point of law. Neither is there an automatic stay of execution when notice of appeal is filed. (Roger Tan, 2012). As far as the STA 1985 is concerned, the provisions for STB merely pay lip-service and till the introduction of the new Act (2013), the STB has never been established in any state in Malaysia. Nevertheless, the court in Gurney Tower Management Corporation \& 3 Others v Commissioner of Building Penang, Penang Municipal Council \& Other [[2011] 6 CLJ 583; [2010] 1 LNS 1821] ruled that in the absence of a Strata Title Board, the COB has the power to adjudicate on issues of management of stratified buildings as provided under section 3 of BCPMMA (Act 663). The role of a COB requires him or her to be "legal officers, law enforcers, mediators at residents' meetings, registrars, record keepers, defect investigators and even debt collectors"." As a legal advisor, the COB must determine the service charge of a property, ensure the building is insured, audit the Building Management Fund, enforce house rules and even advise on late payment interest for maintenance and service charges (NST, 29/9/2007) . Thus, although having court endorsement of their powers and jurisdiction, the $\mathrm{COB}$ faced difficulty in fulfilling the wish of the court as there are no clear guidelines in the law and lack of directive from the Ministry.

In the circumstances, the real players are the staff at the COB's office which is headed by officers who in many aspects lack knowledge and experience in managing problems relating to strata. Based on an interview with the COB of Penang (Zakaria Nayan, 2013) shows that administratively, the office only has one officer and as far as enforcement is concerned, the jobs are shared with the enforcement division. During an interview with the COB Kuala Lumpur, it was revealed that apart from being overburdened, they also lack expertise in handling complaints from the public, in which some of the complaints require investigations and skill in mediation and arbitration. They admitted that there are training provided, but they are inadequate. The authors were also informed that COB does provide training to those involved in strata management but the number of training is limited to once or twice a year covering only around less than 400 people while the number of schemes in Kuala Lumpur alone is more than 4000 (Annual Report, 2013). A similar situation happens in Penang. In fact, briefing or updates on new law or policy organized by private organization normally cost a handsome sum which sometimes put the MC or JMB in a dilemma to spend their money for that purpose. In Australia, free online courses are available to the public (New South Wales Fair Trading).

The latest development in strata laws as proposed in the Strata Title Management Act 2013 shows a serious effort to improve matters pertaining to maintenance and management of the building after a few years of implementation of a specific law dealing with maintenance and management received a lot of complaints from the stakeholders.

In strata management where the owners and the tenants are expected to live in harmony and work as a team, disputes are therefore very unwelcome. Without due attention, they can be exponentially damaging. Thus, it is necessary to create awareness and to establish ways to minimize the chances of them occurring in the first place and, if that doesn't work, to plan strategies to manage them effectively once they occur. The process of dispute avoidance starts with education. The whole community of strata residents must realize the importance of living in harmony, cooperation, having the spirit of brotherhood and tolerance. The process must involve everyone, the developer, the management corporation, the joint management body, the managing agent and more importantly, the owner and the residents in the blocks.

It is also advisable to develop communication avenues such as group blogs or websites, group meetings, face-toface meetings, facilitated strata and building development or planning sessions to bridge gap, remove mistrust and antagonism between the parties. Based on that premise, each organization should have dispute management plan in which a standard of working operation should be devised and made known to those living and managing the strata. In this respect, the Ministry in-charge through the $\mathrm{COB}$ must provide guidelines and find a mechanism to ensure compliance by all parties. For that matter, there is a need to devise incentive or merit base plan, so that all parties can see the benefit of adopting or ignoring the rules. For example, any strata scheme that complies with all the guidelines shall be entitled to a certain kind of incentives from the government in terms of tax incentive etc. Monetary benefits are always found to be attractive. 


\section{Existing Model of Dispute Resolution Methods}

Under the STA Act 318 and the SMA 2013, the MC has a duty to refer disputes or problems to the Strata Management Tribunal or recourse to Magistrates Court on points of law. Under section 53(2) and section 53A (SMA), the MC also has the authority to recover arrears of debt by attachment of any moveable property belonging to the defaulting party. Nevertheless, there is no suggestion for other options of dispute resolutions. Experiences from various other strata jurisdiction such as Singapore, Australia, Canada and Hong Kong show that ADR methods are widely employed either voluntarily or as a pre-requisite for application to Tribunal or even court. In Malaysia, strata stakeholders have a few options to resolve disputes (Shukri, I.M., 2010) such as:

a) Resolving dispute by having a face to face or talk the problem with the other party. This is seen as the best option which is more effective especially for strata stakeholders who need to work and live under one roof or one administration and management. Nevertheless, there should be a standard of practice (SOP) prepared by the JMB or the MC as the parties in dispute may find it difficult to initiate the meeting. It is important to note that resolving strata dispute may need to go beyond determining who is right or wrong. It is about to bring both parties to understand the issue and be willing to remedy and accepting the remedy. Dispute handling procedures should be structured and be made a pre-condition before formal conciliation or mediation.

b) Mediation: Mediation is a voluntary, private dispute resolution process in which a neutral person helps the parties to reach a negotiated settlement. Although discussing the problem is effective for harmonious living, but when the disputing parties are unable to find any acceptable solution, it is advisable to get an independent but neutral party to mediate the dispute. The role of the mediator is to guide the parties in dispute to achieve their own solution. If the management or the parties cannot find any mediator, the $\mathrm{COB}$ may provide the list of the qualified persons to act as a mediator.

\section{The Existing Model of Dispute Resolutions}

Before the establishment of Strata Management Tribunal, most of the complaints go to the Commissioner of Building (COB) such as the office of the City Hall or the office of the Local Authority. Under the job scope of COB the agency has a role to give advice and mediate disputes by attending to complaints from purchasers on defects and poor maintenance as well as the management of common property (Shukri I.M., 2010).

Literature suggests various options for managing disputes. Disputes differ in terms of their levels and any plan of dispute management must consider the differences which in the end determine the expense and finality of outcome. It is usual to expect that the modes of resolving dispute must be practical, low in cost and acceptable by parties in dispute. It is suggested that any $\mathrm{COB}$ office needs to have a proposed plan for ADR and train their staff to keep up with the no-end demands from the industry. 
rocess of Dispute Resolution by Kuala Lumpur City Council (DBKL)

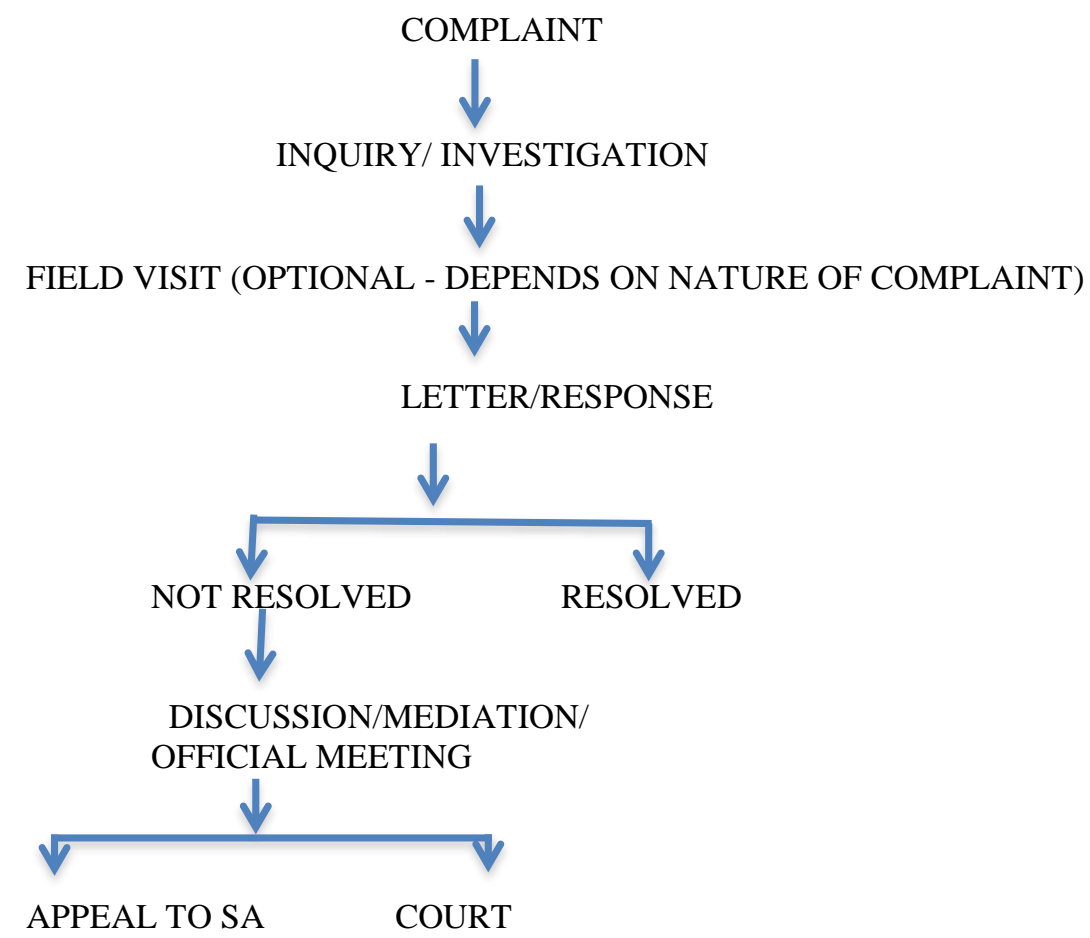

There are advantageous and disadvantageous of various types of ADR and they require consideration for appropriate situations to opt for the mechanisms. It is observed that the effectiveness depends on a case to case having considered the suitability and readiness of the parties involved in the process. In strata management, the mission of dispute resolution is basically to put the parties together under one roof. Thus the way in which strata title disputes are resolved should not be for the sake of making a decision as to who is the winner and who is the loser. Parties to a dispute must still live together under the same roof. The settlement must, where and if possible, restore and build relationships. (Bertus de Villiers, 2011)

Experience has shown that ADR mechanisms such as conciliation and mediation are more appropriate than litigation or full scale arbitration in resolving the vast majority of disputes. There are many advantages of arbitration over litigation which can be summarized as simple procedures with confidentiality assured. The process is not adversarial and often does not require involvement of legal practitioners; emphasis is placed on preserving the relationship between the parties, and where this is not possible, ending the relationship fairly; aims for win-win solution, fast, safe, the process enables the disputants to reach a mutually agreeable solution, rather than having one imposed, with the result that there may be a greater commitment to abiding by the solution.

\section{The ADR within the Tribunal System under the Strata Management Act 2013.}

Realizing there is a need for better option of ADR as well as the calls for cheaper and faster dispute management, the new law was enacted with some background studies on best practices in other jurisdictions including Singapore and Australia. Although Malaysia may be late in introducing the strata titles Tribunal (the Tribunal), its better late than never. The previous discussion has shown proof of unresolved disputes as well as the expectation of parties having problems with strata properties. The new Strata Management Bill 2012 has detailed provisions on the Tribunal covering 25 provisions providing for definition section, the establishment provision, its jurisdiction, the members, the staff, terms of office and allowances, persons entitled to file claim, the sitting of Tribunal, right to appear at hearings, proceeding to be open to public, negotiation for settlement, treatment of parties, rules and procedures, the hearing, appointment of experts, awards, reference to High Court on point of law, criminal penalty for failure to comply with the award as well as the power of the Minister to make Regulations in respect of 
Tribunal. The Fourth Schedule of the Act details out the jurisdictions of the Tribunal, and if the disputes fall outside the scope, the parties have to refer it to the court.

Having mentioned the above, there are still dissatisfactions as regards to some of the new proposed ways to manage strata property. There are still complaints with regards to the term 'property manager' or 'building manager'. There are worries that there will be a monopoly of the industries by certain groups of professionals. As a result, the government had to change some of the concepts after the second reading of the Bill in the parliament. On this point, Malaysia still lacks public consultation practices. In British Columbia, the changes to the Strata Property Act initiated in 2011 aimed to improving accountability in strata corporations were developed through a consultation process that included focus group meetings and an ongoing dialogue with strata experts and organizations. This public input culminated in an online survey carried out in March 2011 to get feedback directly from strata owners and the public. The results of the survey then were then made public.

In Australia, public consultation is common prior to changes in any law or policy. The consultation documents are made available to the public. After the consultation period ends, all responses received will be publicly available from the government agencies' website. A similar process was also done in Singapore where the Ministries concerned will post a document for public consultation and the feedback will go directly to the agencies. For example, the Building and Construction Authority have called for public feedback on the review of the Building Maintenance and Strata Management Act. The public consultation was carried out by an independent third party consulting firm. The survey was done on-line where the public and interested stakeholders were invited to participate. In Malaysia such effort is new. For instance, it was carried out in reviewing the National Land Code 1965 which results are yet to be made public.

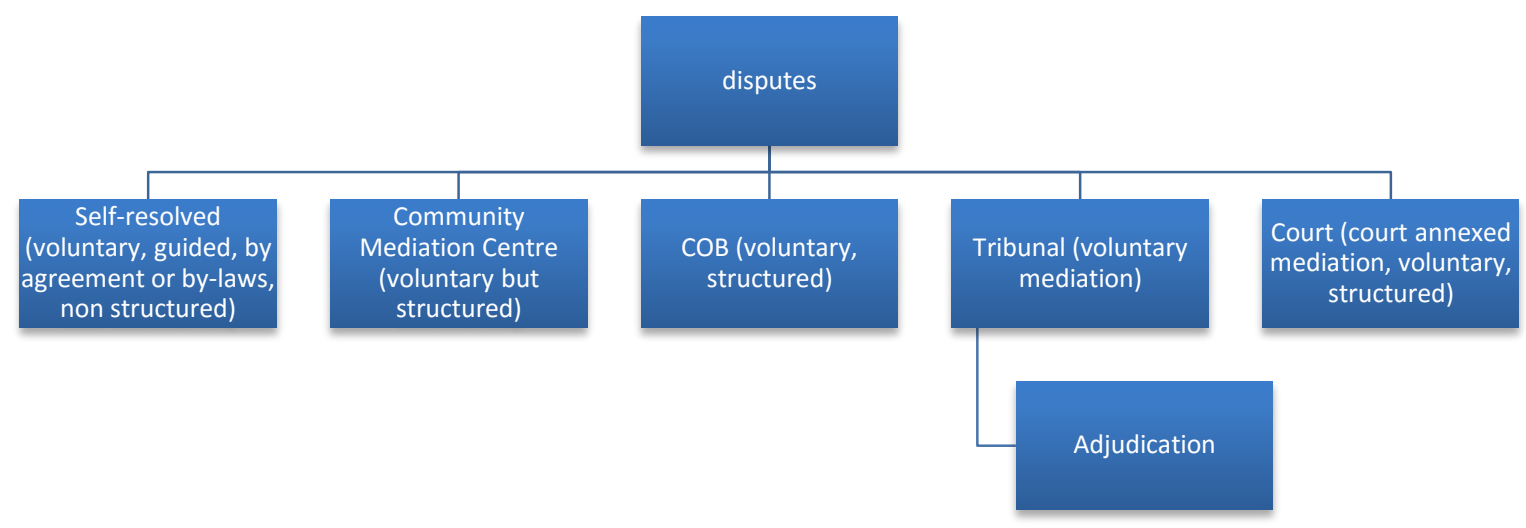

\section{Conclusion}

Fast developments in the law relating to strata properties show there are inadequacies. In this paper, it is shown that there is a lack of implementation and enforcement on what have been determined to be the law. The lacking is administrative as well legal in nature. The root cause may relate to human factors. To address these loopholes, the new bill has provided for the establishment of a Tribunal. Nevertheless, disputes in strata sometimes require more than a simple claim in a Tribunal or court. The Tribunal and litigation should always be regarded as the last, but not the very least resort. Educating people for strata living culture and expectation is more important than living with lifestyles in strata. Guidance may be provided by the management with regard to the process of avoiding and resolving disputes. Final say or award must appear to be effective. Penalty provisions and their enforcement are still necessary. Alternative dispute resolution is relevant in strata living as life in a diversified culture and ethnics bound for differences. 
Acknowledgements

This paper is part of the research project sponsored by the National Institute of Valuation Malaysia (INSPENS).

\section{Bibliografi}

1. Shukri, I.M and Ainul Jaria,M. (2010) Strata Titles law and Procedure. Sweet and Maxwell: Asia

2. Villiers, B (2011) Paper read at the conference entitled "Strata and Community Title in Australia for the 21st Century 2011 " held under the auspices of Griffith University from 7-9 September 2011.

3. Morgan, B.(2008) Dispute Avoidance: A non-confrontational approach to the management of construction contracts, RIBA Publishing

4. Shukri.I.M (2010) A Land Administrator's Guide To Strata Titles in Peninsular Malaysia. Putrajaya: Koperasi Pengurusan Tanah Malaysia Berhad.

5. Bradbrook, A.J, MacCallum, S.V and Moore, A.P. (1991). Australian Real Property Law. Austrlia: The Law Book Company Limited, Australia.

6. Sood, T.K.(2001) Strata Title in Singapore and Malaysia. Second Edition. Butterworth: Asia.

7. Hussain, H. (1999). Akta Hak Milik Strata 1985. Bangi: UKM.

8. Brent E.H. (2005). Building Community - Proven strategies for turning home owners into neighbors . Brent E. Harrington extracted from http://www.mystrata.com/docstore/Bugden_Paper_Current_Challenges.pdf, Community Associations Press . retrieved 23rd January 2013

9. http://www.accc.gov.au/content/item.phtml?itemId=303721\&nodeId=4c2a 7bd149820a $4 \mathrm{f} 6 \mathrm{c} 86 \mathrm{~d} 248 \mathrm{e} 2 \mathrm{~b} 3 \mathrm{cf} 7$ e\&fn=Benchmarks\%20for\%20Dispute\%20Avoidance.pdf, retrieved 21 January 2013

10. Strata Property Act- Improving Accountability Summary of Public Survey Results, www.housing.gov.bc.ca/strata/regs/Summary_SPASurvey1.pdf, retrieved on 24th January 2013. https://www.reach.gov.sg.YourSay/EConsultationPaper/tabid/103/Default.aspx?ssFormAction=\%5B\%5Bs sEConsult_LISTING_BY, retrieved on 24th January 2013

11. Strata Property Act- Improving Accountability Summary of Public Survey Results, www.housing.gov.bc.ca/strata/regs/Summary_SPASurvey1.pdf, retrieved on 24th January 2013.

12. Interview with Zakariya Nayan, COB Penang on 10th of January, 2013.

13. Problems faced by owners of strata titles properties, retrieved from http://www.malaysianbar.org.my/conveyancing_practice/law_realty_problems_faced_by_owners_of_strat a_title_properties.html. Retrieved 21 January 2013

14. The Sun. (2007). http: www. Malaysian retrieved from bar.org.my/conveyancing_practice/law_realty_set_up_strata_titles_board_urges_bar_council.html.

15. NST. 29/9/2007.Report. http://www.hba.org.my/news/2007/907/selangor.html

16. Nor Asiah ,M and Azlinor,S. (2013)

17. Interview with Puan Solehah Nasaruddin , Commissioner of Building, K Lumpur City Council,. August, 2012.

18. Interview with Dr Tiun Ling Ta. School of Social Sciences Penang. 9th January 2013

19. Launching remark in Seminar on Strata Properties Time Bomb; More Solutions or Problems, Sunway Putra Hotel, Kuala Lumpur, 22 January 2013 
20. The National Land Code 1965 (Act 56)

21. The Strata Title Act 1985 (Act 318, Act 1290)

22. The Building and Common Property Act (Management and Maintenance) (Act 663). 2007 http://www.hba.org.my/news/2007/907/selangor.html retrieved 23rd January 2013

23. Fachinger, J. (2006). Behavior of HTR fuel elements in aquatic phases of repository host rock formations. Nuclear Engineering \& Design, 236,54.

24. Fachinger, J., den Exter, M., Grambow, B., Holgerson, S., Landesmann, C., Titov, M., et al. (2004). Behavior of spent HTR fuel elements in aquatic phases of repository host rock formations, 2nd International Topical Meeting on High Temperature Reactor Technology. Beijing, China, paper \#B08.

25. Mettam, G. R., \& Adams, L. B. (1999). How to prepare an electronic version of your article. In B. S. Jones \& R. Z. Smith (Eds.), Introduction to the electronic age (pp. 281-304). New York: E-Publishing Inc.

26. Strunk, W., Jr., \& White, E. B. (1979). The elements of style (3rd ed.). New York: MacMillan.

27. Van der Geer, J., Hanraads, J. A. J., \& Lupton, R. A. (2000). The art of writing a scientific article. Journal of Science Communication, 163, 51-59. 